plant chaired by $\mathrm{Mr}$ Donald Clark who is also an under secretary at the department. A standards and metrology board is also to be established, but the chairman has not yet been appointed.

The boards will take responsibility for the research and development programmes supported by the Department of Trade and Industry in its own laboratories, in industry and in universities, and for those research programmes that the department is to take over from the Natural Environment Research Council in April 1973. In effect they will implement the customer contractor principle within the department, and will spend between them about $£ 15.6$ million a year (see table).

The chairmen's first task will be to appoint the 12 members who will make up each board. These will consist of six independent members from industry, two independent scientists (usually from universities), and members from within the DTI, other government departments, the chief contractors (including the research councils), and staff from the DTI's research divisions. As soon as each board is complete it will survey the area of its responsibilities to assess the current direction of work and any changes that may be needed. The six chairmen of the board will form a separate committee which will meet two to three timees a year to consider broad policy matters, and each board will publish its own annual report.

Mr Heseltine said that plans for separate boards for waste and effluent technology, safety and health and the laboratory of the government chemist had been dropped for the time being,

\section{Royal Commission}

SIR Brian Flowers, Chairman of the Science Research Council, has been appointed Chairman of the Royal Commission on Environmental Pollution in succession to Sir Eric Ashby on his retirement from office on February 20, 1973. Sir Brian will hold the appointment for three years.

Sir Brian Flowers, who has been chairman of the SRC since 1967, is due to retire from that post in October of next year, when he will become Rector of the Imperial College of Science and Technology, University of London. Sir Brian is a theoretical physicist by training, holding degrees from the Universities of Cambridge and Birmingham, and his former posts include those of Head of the Theoretical Physics Division at Harwell, Chief Research Scientist at Harwell, and Langworthy Professor of Physics at the University of Manchester. but he emphasized that "we are starting a new system (with the requirements boards) and if it doesn't work we'll divide them, or they can divide themselvès."

$\mathrm{Mr}$ Heseltine also said that he was anxious that each board should have at its disposal, not only the necessary technical skills to deal with its subject, but also the necessary economic, marketing and public relations skills to take advantage of any successes.

On the question of conflict of interests when industrial members of the boards have to advise on research into areas that might affect their own businesses, $\mathrm{Mr}$ Heseltine said that whereas the problem was a difficult one, he hoped that the good sense of the board members and the activities of the DTI's staff would prevent difficulties occurring. It would be wrong, he implied, to cut off the advice of industry simply to establish a principle.

Expenditure on Research and Development within the Department of Trade and Industry

\begin{tabular}{lc}
\hline & $\begin{array}{c}£ \text { million } \\
\text { (approx.) }\end{array}$ \\
Civil Aerospace & 109 \\
Reactor and nuclear research & 43 \\
$\begin{array}{l}\text { Industrial Research } \\
\text { Establishments, Research } \\
\text { Associations and contract } \\
\text { research* }\end{array}$ & \\
& 26 \\
\hline
\end{tabular}

* $£ 15.6$ million of this is to be spent by the requirements boards; the remainder is for providing direct assistance to industry on full repayment terms.

The requirements boards were first made public seven months ago by $\mathrm{Sir}$ Robert Marshall, secretary for industry at the DTI, when he gave evidence before the Select Committee on Science and Technology. Mr Heseltine's only explanation for the delay is that the administration needed to set up a new concept of research and development management took longer than he anticipated.

\section{MEDICINE \\ Trauma over Trauma}

TODAY about 13,700 people will be injured sufficiently seriously in England and Wales to have to attend hospital. Nearly half a million people, occupying ten per cent of available beds, are admitted to hospital each year as a result of being injured. Yet less is known about the pathology of trauma than about many other aspects of ill health which cause far less mortality and morbidity.

This accusation of neglect comes from a working party of the Royal College of Pathologists which began work in 1967 and has just issued its

\section{New Appointment}

Professor Leslie Fowden, University College, University of London, has been appointed as Director of the Rothamsted Experimental Station in succession to Sir Frederick Bawden who died in February.

Professor Fowden, who has been professor of plant chemistry at University College since 1964, is 47 and has been a fellow of the Royal Society since 1964 . He will take up his new appointment in the spring of 1973 .

report with a string of recommendations as to how the situation can be improved.

The Medical Research Council should consider setting up special units to study the pathology of trauma, the University Grants Committee should finance multidisciplinary departments of experimental pathology to concentrate on trauma, and the General Medical Council should encourage medical schools to give greater emphasis to the study of trauma at undergraduate level. A Combined Forces Institute of Traumatic Pathology should be established by the Ministry of Defence to provide a national focus for research and a number of major accident centres should also be designated as centres of research into the subject.

Education, the working party says, will have to begin at an early stage in the educational cycle as there are so few experts on trauma in Britain, and attempts should be made to improve the statistics of trauma and its complications. And just to prove that the Royal College of Pathologists is not attempting to put other people's houses in order while ignoring its own back yard, the working party recommends that a greater knowledge of the pathology of trauma should be required of candidates in its own examinations.

As a result of the working party's report, the college has already been in touch with the Registrar General's office to encourage it to improve its compilation of statistics on injuries, and with the British delegates to the World Health Organisation who will be revising the organization's definitions of types of accident over the next three years.

But for real progress to be made more money will have to be put into research. Dr H. B. Stoner, the working party's chairman, said last week that trauma costs Britain more than $£ 1$ million a day; "we suggest spending rather less than one per cent of that on research, and if we cannot afford to spend any more, we cannot, perhaps, afford to spend much less". 